\title{
Antimicrobial and Anti-Oxidative Activities of 12-Arylbenzoacridines
}

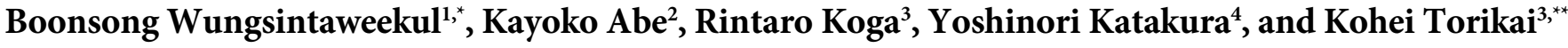 \\ ${ }^{1}$ School of Pharmacy, Walailak University, 222 Thaiburi, Thasala, Nakhon Si Thammarat 80161, Thailand \\ ${ }^{2}$ Graduate School of Systems Life Sciences, Kyushu University, 744 Motooka, Nishi-ku, Fukuoka 819-0395, Japan \\ ${ }^{3}$ Department of Chemistry, Graduate School and Faculty of Science, Kyushu University, 744 Motooka, Nishi-ku, \\ Fukuoka 819-0395, Japan
}

${ }^{4}$ Faculty of Agriculture, Kyushu University, 744 Motooka, Nishi-ku, Fukuoka 819-0395, Japan

\section{* Corresponding author:}

email: boonsong.wu@mail.wu.ac.th*; torikai@chem.kyushu-univ.jp

Received: January 15, 2020

Accepted: January 30, 2020

DOI: $10.22146 /$ ijc. 53411

\begin{abstract}
Searching biologically active compounds has been one of the major duties of organic chemists. We previously constructed a library of synthetic 12-arylbenzoacridines and found estrogenic and anti-estrogenic agents. With taking the shot-gun approach into consideration, further exploration for bioactive species in the above library was carried out. As a result, new antibacterial agents against $\mathrm{S}$. aureus $(M I C=16 \mu M)$, E. coli $(M I C$ $=7.8 \mu \mathrm{M})$, E. faecalis $(M I C=0.98 \mu \mathrm{M})$, and A. baumannii $(M I C=31 \mu M)$ were found. Moreover, we also unveiled that some of the tested compounds exhibit cell-based antioxidative activity. These results clearly show a good potential of 12-arylbenzoacridines as novel pharmacophores, which is useful to establish various medicines.
\end{abstract}

Keywords: benzoacridine; antibacterial; shotgun approach; antioxidant

\section{- INTRODUCTION}

Continuous establishments of novel antimicrobial agents are inevitable for human beings, because of an endless vicious spiral of newly developed drugs and their invalidation by microorganisms. Although millions of researchers in pharmaceutical industries and academia are struggling to develop effective medicines even today, the drug discovery usually suffers from consumptions of a very long time (12 or more years) and huge amount of expenses (over $\$ 1$ billion/small molecule), as well as its low success rate $(0.17 \%$, to have 1 small molecule drug launch from hit compounds) [1]. Statistically, it is said that a successful drug is generated from 30,000 dropped compounds. It had been considered until a couple of decades ago that a molecular target of a drug should be single to suppress unfavorable side effects. However, recently, the concept has changed to the one called "shot-gun approach" or "polypharmacology" (for selected reviews, see [2-9]), in which drugs are allowed to interact with several biomolecules that differ from the main target unless the second interaction causes serious side effects. This conceptual shift might have occurred to compensate for the low success rate of drug discovery and to continue to win the endless race with microorganisms.

We have been engaged in the researches on aromatic heterocycles in the interdisciplinary field between organic and medicinal chemistry [10], and reported syntheses of a dibenzonaphthyridine (4) [11], and a series of benzoacridines (5-23) via the thermal cyclization of precursors A and B, with their biological activities (Fig. 1) [12-13]. From the established synthetic benzoacridine library, it was revealed [13] that compounds 9, 14, and 18, having electron-withdrawing substituents, inhibited the estradiol-induced proliferation of a breast cancer cell line MCF-7, with $\mathrm{LD}_{50}$ values of $9.1,9.2$, and $4.0 \mu \mathrm{M}$, respectively, i.e., they show anti-estrogenic activity, which is important to develop, e.g., anti-breast cancer agents. In contrast, hydroxylated compounds $\mathbf{6}, \mathbf{1 1}$, and $\mathbf{1 6}$ showed the opposite property, i.e., these compounds bind to the estrogen receptors (ER) $\alpha$ and $\beta$ strongly $\left(\mathrm{IC}_{50}=154-\right.$ $1083 \mathrm{nM}$ ), and exert agonistic activity with estradiol 


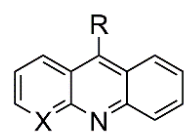

1: $\mathrm{X}=\mathrm{CH}, \mathrm{R}=\mathrm{H}$

2: $\mathrm{X}=\mathrm{CH}, \mathrm{R}=\mathrm{Ph}$

3: $\mathrm{X}=\mathrm{N}, \mathrm{R}=\mathrm{Ph}$

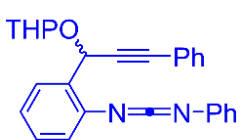

A
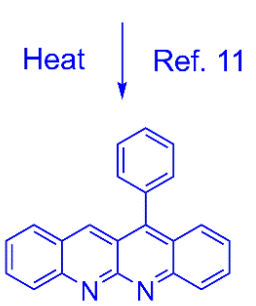

4

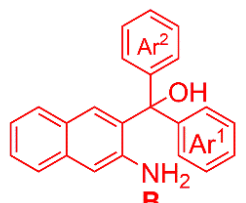

B

Heat $\downarrow$ Ref. 12, 13

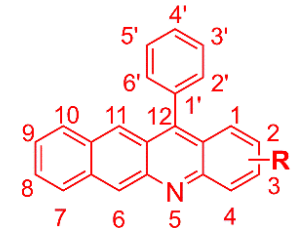

5: $\mathrm{R}=\mathrm{H} \quad$ 14: $\mathrm{R}=9-\mathrm{CF}_{3}$

6: $\mathrm{R}=3-\mathrm{OH} \quad$ 15: $\mathrm{R}=2^{\prime}-\mathrm{CF}_{3}$

7: $\mathrm{R}=3-\mathrm{OMe} \quad$ 16: $\mathrm{R}=4^{\prime}-\mathrm{OH}$

8: $\mathrm{R}=3-\mathrm{CF}_{3}$ 17: $\mathrm{R}=4^{\prime}-\mathrm{OMe}$

9: $\mathrm{R}=6-\mathrm{Cl} \quad$ 18: $\mathrm{R}=4^{\prime}-\mathrm{CF}_{3}$

10: $R=6-C N \quad$ 19: $R=4^{\prime}-1,2,4$-triazole

$\begin{array}{ll}\text { 11: } R=9-O H & 19: R=4^{\prime}-1,2,4-\text { triazol } \\ \text { 20: } R=9,4^{\prime}-\text { bis }\left(\mathrm{CF}_{3}\right)\end{array}$

12: $R=9-\mathrm{OMe}$ 21: $\mathrm{R}=3-\mathrm{OM}$ - $\mathrm{CN}-4^{\prime}-$-bis $\left(\mathrm{CF}_{3}\right)$

22: $R=3,9,4^{\prime}$-tris $\left(\mathrm{CF}_{3}\right)$

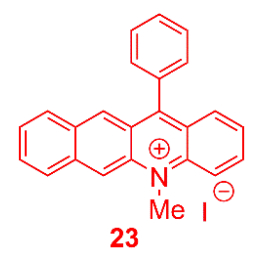

Fig 1. Structures of the tested aromatic amines 1-23

against $\mathrm{ER} \alpha\left(\mathrm{EC}_{50}=1.3-7.4 \mu \mathrm{M}\right)$. This estrogenic activity might be useful for the development of drugs for hormone replacement therapy, e.g., to treat osteoporosis, menopausal disorders, ovariectomy, etc.

Having found a good potential of our library to discover novel biologically active compounds, we decided to subject this library to the "shot-gun approach" to explore the further biological utility of our newly introduced 12-arylbenzoacridine scaffold. Indeed, to the best of our knowledge, no biological activities of this series of arylbenzoacridines, other than our previous work on (anti-) estrogenic one, have been reported to date. However, a few benz $[c]$ acridines, curved congeners of our benz[b]acridines, are known as weak antimicrobial [1415] and immunomodulative [16] agents. Herein, we report a successful selection of antimicrobial and radical scavenging benzoacridines from our library.

\section{- EXPERIMENTAL SECTION}

\section{Chemicals}

Compounds 1-3 were purchased from local vendors and used as supplied. The benzonaphthyridine compound 4 was synthesized and purified according to the literature [11]. 12-Phenylbenzoacridines 5-23 were synthesized and purified according to the literature [12-13].

\section{Antimicrobial Assay}

Antimicrobial activities of all the samples against S. aureus ATCC 25923, E. coli ATCC 25922, E. faecalis, $K$. pneumonia, A. baumanii, $P$. aeruginosa and $C$. albicans were tested. A broth microdilution assay method, developed by Balouiri et al. [17], was modified and applied to our experiment. S. aureus and E. coli were standard bacteria, and others were isolated from patients at the Maharaja Nakhon Si Thammarat Hospital. All bacteria were cultured on tryptone soya agar (TSA), and C. albicans was cultured on Sabouraud dextrose agar (SDA) media ( $24 \mathrm{~h}$ ) before conducting assays. In the assays, E. faecalis was cultured in Brain Heart Infusion (BHI) broth $(2 \mathrm{~mL})$ for $3 \mathrm{~h}$, and C. albicans was in Sabouraud dextrose broth (SDB) media $(2 \mathrm{~mL})$ for $3 \mathrm{~h}$. All other bacteria were cultured in Mueller Hinton broth (MHB) media $(2 \mathrm{~mL})$ for $3 \mathrm{~h}$. The turbidity of all tubes of microbes was measured by a spectrophotometer and adjusted to 0.5 McFarland with each medium. All microbes were diluted by 100 times with sterile normal saline before the addition of samples, except $C$. albicans. Microbe suspensions $(10 \mu \mathrm{L})$ were added to sample 
solutions $(100 \mu \mathrm{L})$, which had been prepared by serial dilution of stock DMSO solutions $(100 \mu \mathrm{L})$ using MHB media $(100 \mu \mathrm{L})$ to give $500 \mu \mathrm{M}$ to $0.980 \mu \mathrm{M}$, and the experiments were repeated 3 times at each concentration. After the incubation at $37^{\circ} \mathrm{C}\left(25^{\circ} \mathrm{C}\right.$ for a fungus) for 24 $\mathrm{h}$, resazurin $(1.69 \mathrm{mg} / \mathrm{mL}$ in deionized water, $10 \mu \mathrm{L})$, as a growth indicator, was added to each well and incubated for further $3 \mathrm{~h}$. Active living microorganism cause reduction of resazurin (purple-blue) to resorufin (pinkcolorless). The lowest concentration of each sample, which could inhibit the growth of a microbe, was recorded as minimum inhibitory concentration (MIC) of the sample. Then $10 \mu \mathrm{L}$ of a mixture of a microbe and a sample, which could inhibit the growth, was transferred to MHA media $(20 \mathrm{~mL})$ on plate and incubated for $12 \mathrm{~h}$. The lowest concentration of each sample, which could completely kill the microbe, was recorded as minimum microbicidal concentration (MMC) of the sample. Erythromycin and ketoconazole were tested as positive controls for antibacterial and antifungal, respectively.

\section{DPPH Radical Scavenging Assay}

The radical scavenging activity of compounds 1-23 and L-ascorbic acid (positive control) was evaluated using DPPH as a free radical, via the method described by Braca et al. [18]. Briefly, all samples were dissolved in DMSO at $1.00 \mathrm{mM}$, and diluted with DMSO by 10-fold serial dilution to $0.100 \mu \mathrm{M}$. A group of DMSO solutions $(100 \mu \mathrm{L}$ each) was treated with DPPH $(0.00400 \%$, in $\mathrm{MeOH}, 100 \mu \mathrm{L}$ each), and another group was done without DPPH (i.e., $100 \mu \mathrm{L}$ each of $\mathrm{MeOH}$ was added). The reaction was carry out at room temperature for $30 \mathrm{~min}$, then the absorbance at $517 \mathrm{~nm}(\mathrm{Ab})$ was recorded on a microplate reader. The percentage of scavenging activity of each sample (\%SC) was calculated by the Eq. (1). From the dose-response sigmoidal curves, $\mathrm{SC}_{50}$ was calculated when it was observed within the tested highest concentration.

$$
\% \mathrm{SC}=\frac{100\left\{\left(\mathrm{Ab}_{\text {control }}-\mathrm{Ab}_{\text {control blank }}\right)-\left(\mathrm{Ab}_{\text {sample }}-\mathrm{Ab}_{\text {sample blank }}\right)\right\}}{\left(\mathrm{Ab}_{\text {control }}-\mathrm{Ab}_{\text {control blank }}\right)}
$$

\section{Cell-Based ROS Scavenging Assay}

Production of intracellular reactive oxygen species (ROS) in human keratinocyte $\mathrm{HaCaT}$ cells was measured using BES- $\mathrm{H}_{2} \mathrm{O}_{2}$-Ac (FUJIFILM Wako Pure Chemical
Corporation, Japan) according to the manufacturer's protocol [19]. HaCaT cells were treated with compound 11 or $23(10 \mu \mathrm{M})$ for $48 \mathrm{~h}$. The medium was removed, and cells were washed twice with 4-(2-hydroxyethyl)-1piperazineethanesulfonic acid (HEPES) buffer ( $\mathrm{pH}$ 7.4). The cells were incubated with $5 \mu \mathrm{M}$ BES- $\mathrm{H}_{2} \mathrm{O}_{2}$ - $\mathrm{Ac}$ and Hoechst 33342 (Dojin, Japan) in HEPES (pH 7.4) at $37^{\circ} \mathrm{C}$ for $30 \mathrm{~min}$, followed by detection with an IN Cell Analyzer 2200 (GE Healthcare, Amersham Place, UK).

\section{- RESULTS AND DISCUSSION}

First, we carefully selected representative five Gram-negative, one Gram-positive (Staphylococcus aureus) bacteria and a fungus (Candida albicans) that frequently cause public health problems to humans. Staphylococcus aureus (S. aureus) acts as a common cause of skin and respiratory infections, as well as food poisoning [20-21]. Although most Escherichia coli (E. coli) strains are harmless, some phenotypes, such as O157, are causative pathogens of serious food poisoning, occurring even in developed countries [22]. Enterococcus faecalis (E. faecalis) is another notorious pathogen for food poisoning [23]. Aspiratory infection of Klebsiella pneumoniae (K. pneumoniae) occasionally causes destructive damage to animal and human lungs [24], while Acinetobacter baumannii (A. baumannii) [25] and Pseudomonas aeruginosa (P. aeruginosa) [26] are problematic due to their opportunistic infection of people with immunodeficiency. Since fungi can also affect our health, as a representative fungus, Candida albicans (C. albicans), which infects on mucous membranes, e.g., in the mouth or vagina [27], was chosen to be subjected to the treatment with our compounds.

\section{Antimicrobial Activity}

Antimicrobial activities of 1-23 were tested by a broth microdilution method [17], and the minimum inhibitory concentration (MIC) and the minimum microbicidal concentration (MMC) were depicted in Table 1. Against $S$. aureus, only two cationic species, i.e., a benzoacridine possessing a 4'-triazole substituent (19, entry 19) and an ammonium salt $\mathbf{2 3}$ (entry 23), were active to show MICs of 31 and $16 \mu \mathrm{M}$, as well as MMCs 
of 63 and $16 \mu \mathrm{M}$, respectively. For E. coli, only the ammonium salt $\mathbf{2 3}$ (entry 23) was very effective, to have its MIC at $7.8 \mu \mathrm{M}$ and MMC at $16 \mu \mathrm{M}$. The growth of $E$. faecalis was inhibited by the treatment with benzoacridines possessing $3-\mathrm{OH}(6$, entry 6$)$ and positively-charged ammonium moieties (23, entry 23$)$. A preliminary structure-activity-relationship (SAR) implied that the oxygen substituent at 3-position is necessary and it may interact with the target molecule in E. faecalis, via hydrogen bonding. On the other hand, it was revealed that many 12-arylbenzoacridine derivatives have no inhibitory activity against $K$. pneumoniae, $P$. aeruginosa and the fungus, $C$. albicans. In the case of $A$. baumannii, naphthyridines $\mathbf{3}$ and $\mathbf{4}$ were as effective as benzoacridine derivatives $6,7,10,11,13,17$, and $22(\mathrm{MICs}=31-63 \mu \mathrm{M})$, but all of these behaved only bacteriostatically. The most potencies of 6, to, e.g., E. faecalis, and A. baumannii, suggest the importance of the 3-OH group, which may form a hydrogen bond with the targets. The activity of 10, 11, and 13 implied that a polar substituent would be favorable at 6- and 9-positions to exert antibacterial activities, whereas that of $\mathbf{1 7}$ and $\mathbf{2 2}$ implied a substituent, which is a little bigger than hydrogen (such as $\mathrm{OMe}$ and $\mathrm{CF}_{3}$ ) would act positively. Finally, by taking a survey of the antimicrobial activities in Table 1, we concluded that compound $\mathbf{2 3}$ is the most reliable candidate to establish a new compound with a broad antimicrobial spectrum, while compounds $\mathbf{6}$ would be

Table 1. Antimicrobial activities of compounds 1-23 (broth microdilution method) ${ }^{\mathrm{a}}$

\begin{tabular}{|c|c|c|c|c|c|c|c|}
\hline \multirow{2}{*}{$\begin{array}{c}\text { Entry } \\
\text { (compound) }\end{array}$} & S. aureus & E. coli & E. faecalis & K. pneumoniae & A. baumannii & P. aeruginosa & C. albicans \\
\hline & \multicolumn{7}{|c|}{ MIC/MMC $(\mu \mathrm{M})$} \\
\hline $1(\mathbf{1})$ & $\mathrm{NO}$ & $\mathrm{NO}$ & $\mathrm{NO}$ & $\mathrm{NO}$ & $\mathrm{NO}$ & ND & ND \\
\hline $2(2)$ & $\mathrm{NO}$ & NO & NO & $\mathrm{NO}$ & $\mathrm{NO}$ & ND & ND \\
\hline $3(3)$ & $\mathrm{NO}$ & $\mathrm{NO}$ & $\mathrm{NO}$ & ND & $63 / \mathrm{ND}$ & ND & ND \\
\hline $4(4)$ & NO & $\mathrm{NO}$ & $\mathrm{NO}$ & $\mathrm{NO}$ & $63 / \mathrm{ND}$ & ND & ND \\
\hline $5 \quad(5)$ & $\mathrm{NO}$ & $\mathrm{NO}$ & $\mathrm{NO}$ & $\mathrm{NO}$ & NO & ND & ND \\
\hline $6(6)$ & NO & NO & $0.98 / 130$ & ND & $31 / \mathrm{ND}$ & ND & ND \\
\hline $7(7)$ & $\mathrm{NO}$ & $\mathrm{NO}$ & ND & ND & $63 / \mathrm{ND}$ & ND & ND \\
\hline $8(8)$ & NO & NO & NO & NO & NO & ND & ND \\
\hline $9 \quad(9)$ & $\mathrm{NO}$ & $\mathrm{NO}$ & $\mathrm{NO}$ & ND & $\mathrm{NO}$ & ND & ND \\
\hline $10(10)$ & $\mathrm{NO}$ & NO & ND & ND & $63 / \mathrm{ND}$ & ND & ND \\
\hline $11(11)$ & NO & $\mathrm{NO}$ & NO & ND & $63 / \mathrm{ND}$ & ND & ND \\
\hline $12(\mathbf{1 2})$ & $\mathrm{NO}$ & $\mathrm{NO}$ & $\mathrm{NO}$ & ND & $\mathrm{NO}$ & ND & ND \\
\hline $13(13)$ & $\mathrm{NO}$ & $\mathrm{NO}$ & $\mathrm{NO}$ & $\mathrm{NO}$ & $63 / \mathrm{ND}$ & ND & ND \\
\hline $14 \quad(\mathbf{1 4})$ & $\mathrm{NO}$ & $\mathrm{NO}$ & $\mathrm{NO}$ & ND & NO & ND & ND \\
\hline $15(15)$ & NO & NO & NO & NO & NO & ND & ND \\
\hline $16(16)$ & $\mathrm{NO}$ & $\mathrm{NO}$ & $\mathrm{NO}$ & $\mathrm{NO}$ & $\mathrm{NO}$ & ND & ND \\
\hline $17(\mathbf{1 7})$ & NO & NO & $\mathrm{NO}$ & $\mathrm{NO}$ & $63 / \mathrm{ND}$ & ND & ND \\
\hline $18(18)$ & $\mathrm{NO}$ & NO & $\mathrm{NO}$ & $\mathrm{NO}$ & NO & ND & ND \\
\hline $19(\mathbf{1 9})$ & $31 / 63$ & $\mathrm{NO}$ & $\mathrm{NO}$ & $\mathrm{NO}$ & NO & ND & ND \\
\hline $20 \quad(\mathbf{2 0})$ & $\mathrm{NO}$ & $\mathrm{NO}$ & $\mathrm{NO}$ & $\mathrm{NO}$ & $\mathrm{NO}$ & ND & ND \\
\hline $21 \quad(21)$ & $\mathrm{NO}$ & $\mathrm{NO}$ & $\mathrm{NO}$ & $\mathrm{NO}$ & $\mathrm{NO}$ & ND & ND \\
\hline $22 \quad(22)$ & NO & NO & NO & $\mathrm{NO}$ & $63 / \mathrm{ND}$ & ND & ND \\
\hline $23 \quad(23)$ & $16 / 16$ & $7.8 / 16$ & $63 / 130$ & ND & NO & ND & ND \\
\hline Erythromycin & $0.080 / 39$ & $4.9 / 310$ & $0.31 / \mathrm{ND}$ & $39 / \mathrm{ND}$ & $39 / 160$ & $20 / \mathrm{ND}$ & - \\
\hline Ketoconazole & - & - & - & - & - & - & $200 / \mathrm{ND}$ \\
\hline
\end{tabular}

${ }^{\text {a }} \mathrm{ND}=$ not determined; although very weak inhibition was observed, the values could not be determined in the tested concentration range, due to low activity. $\mathrm{NO}=$ not observed; no inhibition was observed at the tested highest concentration (130 $\mu \mathrm{M}$ for MIC, $250 \mu \mathrm{M}$ for MMC) 
the second to 23. Despite the enormous antimicrobial heterocycles available to date (for a recent example from this journal, see [28]), few are known upon benzoacridines. Therefore, it is difficult to compare our results generated from a unique core with the others, but an only example was reported by Motohashi and coworkers that non-substituted benz[c]acridine showed antimicrobial activities against $S$. aureus (MIC $>218 \mu \mathrm{M}$ ), E. coli K12LE140 $(\mathrm{MIC}=568 \mu \mathrm{M})$, P. aeruginosa $(\mathrm{MIC}>$ $218 \mu \mathrm{M}$ ), and C. albicans (MIC > $218 \mu \mathrm{M})$ [14]. By comparison, our compound 23 seems to be ca. 14- and 73fold more potent than benz $[c]$ acridine, against $S$. aureus and E. coli, respectively. Although it is obvious that the difference should be due to the linear tetracyclic core structure, an aromatic ring at $\mathrm{C} 12$ position, and/or a charged character of $\mathbf{2 3}$, it would be difficult to identify the main factor(s) for the enhanced antimicrobial activity.

\section{Radical Scavenging Activity}

\section{DPPH assay}

After concluding the antimicrobial effects, we continued to "fire our shot-gun", to hit another target, i.e., the radical scavenging activity of this class of compounds (Table 2). Initial search was performed via a widely accepted chemical method, using 2,2-diphenyl-1picrylhydrazyl (DPPH) [24], to confirm whether our compounds have potential to work as radical scavengers, or not. Therefore, we did not calculate the $50 \%$ radical scavenging concentration $\left(\mathrm{SC}_{50}\right)$ values very precisely at this stage. Instead, we roughly estimated the activities from a small number ( 3 or 4 ) of data points, and the results were shown by,+++ , and +++ , for activities of $\mathrm{SC}_{50}$ $=\mathrm{ca}$. three-, two-, and one-digit (or less) numbers $\mu \mathrm{M}$, respectively. As a result, it was found that compounds $\mathbf{1}$, 2, and $\mathbf{1 0}$ have weak, compounds $\mathbf{8}, \mathbf{1 1}$, and $\mathbf{2 2}$ have moderate, and most interestingly, compound $\mathbf{2 3}$ has potent DPPH scavenging activity.

\section{Cell-based reactive oxygen species scavenging assay}

Finally, we tested the reactive oxygen species (ROS) scavenging activity of hit compounds $\mathbf{1 1}$ and $\mathbf{2 3}$, against human keratinocyte, HaCaT cell line [19]. As a result, 9hydroxy (11) and 5- $\mathrm{N}$-methyl (23) derivatives were revealed to show ROS scavenging activity, at only $10 \mathrm{nM}$,
Table 2. DPPH radical scavenging activities of $\mathbf{1}-\mathbf{2 3}^{\mathrm{a}}$

\begin{tabular}{|c|c|}
\hline Entry (compound) & DPPH Radical Scavenging \\
\hline $1(1)$ & $\mathrm{NO}$ \\
\hline $2(2)$ & NO \\
\hline $3(3)$ & ND \\
\hline $4(4)$ & NO \\
\hline $5(5)$ & ND \\
\hline $6(6)$ & NO \\
\hline 7 (7) & ND \\
\hline $8(8)$ & ++ \\
\hline $9(9)$ & NO \\
\hline $10(\mathbf{1 0})$ & + \\
\hline $11(11)$ & ++ \\
\hline $12(12)$ & NO \\
\hline $13(13)$ & NO \\
\hline $14(14)$ & ND \\
\hline $15(15)$ & NO \\
\hline $16(16)$ & NO \\
\hline $17(17)$ & ND \\
\hline $18(\mathbf{1 8})$ & NO \\
\hline $19(19)$ & $\mathrm{NO}$ \\
\hline $20(\mathbf{2 0})$ & ND \\
\hline $21(21)$ & NO \\
\hline $22(\mathbf{2 2})$ & ++ \\
\hline $23(23)$ & +++ \\
\hline
\end{tabular}

a $\mathrm{ND}=$ not determined; although very weak activity was observed, the values could not be determined in the tested concentration range, due to low activity. $\mathrm{NO}=$ not observed; no inhibition was observed at the tested highest concentration $(500 \mu \mathrm{M}$ for DPPH). NT $=$ not tested. ${ }^{\mathrm{b}}+$ represents $\mathrm{SC}_{50}=$ three-digit number $\mu \mathrm{M} .++$ represents $\mathrm{SC}_{50}=$ two-digit number $\mu \mathrm{M}$, and +++ represents $\mathrm{SC}_{50} \leq$ one-digit number $\mu \mathrm{M}$

to decrease the ROS levels to $79 \%$ and $72 \%$, respectively, compared with the DMSO vehicle control (for details, see Supplementary Data).

It is interesting to find that even in totally different assay systems (i.e., estrogen-related, antimicrobial, and radical scavenging activities). The same types of compounds, such as hydroxylated and $\mathrm{N}$-methylated ones, were always active although the side effects caused by a polyaromatic structure should more carefully be addressed.

\section{- CONCLUSION}

In summary, from our synthetic library of 12arylbenzoacridines, it was discovered that 12-phenyl benzo $[b]$ acridin-3-ol (6) shows potent antimicrobial activities against $E$. faecalis (MIC $=0.98 \mu \mathrm{M}$ ), while 5- 
methyl-12-phenylbenzo[b]acridinium iodide (23) does against S. aureus and E. coli $(\mathrm{MIC}=16$ and $7.8 \mu \mathrm{M}$, respectively). Some members of 12-arylbenzoacridines exerted weak antimicrobial activities, and others have a potential as a radical scavenger. In particular, 12phenylbenzo[b]acridin-9-ol (11) and 23 were revealed to scavenge reactive oxygen species in the cell-based assay. These findings indicate that the 12-arylbenzoacridine core is a useful scaffold to establish novel antimicrobial and radical scavenging agents.

\section{- ACKNOWLEDGMENTS}

This work was partially supported by a grant from the Fukuoka Foundation for Sound Health (to K.T.). B.W. and K.T. thank the financial support by Walailak University for inviting K.T. to Walailak University to start this collaboration. We thank Mr. Peter Hall, who teaches at Hiramatsu Educational Group, Oita, Japan, for his English proofreading. This paper is dedicated to Prof. Hiroshi Noguchi in Nihon Pharmaceutical University, Japan, on the occasion of his $70^{\text {th }}$ birthday.

\section{- SUPPORTING INFORMATION}

Fig. S1: DPPH radical scavenging activity of $\mathbf{8}$, Fig. S2: DPPH radical scavenging activity of 10, Fig. S3: DPPH radical scavenging activity of 11, Fig. S4: DPPH radical scavenging activity of 23, Fig. S5: Reactive oxygen species scavenging activity of compounds $\mathbf{1 1}$ and $\mathbf{2 3}$.

\section{- REFERENCES}

[1] Mohs, R.C., and Greig, N.H., 2017, Drug discovery and development: Role of basic biological research, Alzheimers Dement., 3 (4), 651-657.

[2] Gilberg, E., and Bajorath, J., 2019, Recent progress in structure-based evaluation of compound promiscuity, ACS Omega, 4 (2), 2758-2765.

[3] Proschak, E., Stark, H., and Merk, D., 2019, Polypharmacology by design: A medicinal chemist's perspective on multitargeting compounds, J. Med. Chem., 62 (2), 420-444.

[4] Bolognesi, M.L., and Cavalli, A., 2016, Multitarget drug discovery and polypharmacology, ChemMedChem, 11 (12), 1190-1192.
[5] Rosini, M., 2014, Polypharmacology: The rise of multitarget drugs over combination therapies, Future Med. Chem., 6 (5), 485-487.

[6] Anighoro, A., Bajorath, J., and Rastelli, G., 2014, Polypharmacology: Challenges and opportunities in drug discovery, J. Med. Chem., 57 (19), 78747887.

[7] Reddy, A.S., and Zhang, S., 2013, Polypharmacology: Drug discovery for the future, Expert Rev. Clin. Pharmacol., 6 (1), 41-47.

[8] Peters, J.U., 2013, Polypharmacology-foe or friend?, J. Med. Chem., 56 (22), 8955-8971.

[9] Hopkins, A.L., 2008, Network pharmacology: The next paradigm in drug discovery, Nat. Chem. Biol., 4 (11), 682-690.

[10] Torikai, K., Otsuka, Y., Nishimura, M., Sumida, M., Kawai, T., Sekiguchi, K., and Ueda, I., 2008, Synthesis and DNA cleaving activity of watersoluble non-conjugated thienyl tetraynes, Bioorg. Med. Chem., 16 (10), 5441-5451.

[11] Kimura, H., Torikai, K., and Ueda, I., 2009, Thermal cyclization of nonconjugated aryl-ynecarbodiimide furnishing a dibenzonaphthyridine derivative, Chem. Pharm. Bull., 57 (4), 393-396.

[12] Koga, R., Oishi, T., and Torikai, K., 2015, Tuned classical thermal aromatization furnishing an estrogenic benzoacridine, Synlett, 26 (20), 28012805.

[13] Torikai, K., Koga, R., Liu, X., Umehara, K., Kitano, T., Watanabe, K., Oishi, T., Noguchi, H., and Shimohigashi, Y., 2017, Design and synthesis of benzoacridines as estrogenic and anti-estrogenic agents, Bioorg. Med. Chem., 25 (20), 5216-5237.

[14] Motohashi, N., Sakagami, H., Kurihara, T., Ferenczy, L., Csuri, K., and Molnar, J., 1992, Antimicrobial activity of phenothiazines, benzo $[a]$ phenothiazines and benz $[c]$ acridines, Anticancer Res., 12 (4), 1207-1210.

[15] Molnar, J., Sakagami, H., and Motohashi, N., 1993, Diverse biological activities displayed by phenothiazines, benzo[a]phenothiazines and benz $[c]$ acridines, Anticancer Res., 13 (4), 10191025. 
[16] Molnar, J., Mandi, Y., Petri, I., Petofi, S., Sakagami, H., Kurihara, T., and Motohashi, N., 1993, Immunomodulation activity of phenothiazines, benzo $[a]$ phenothiazines and benz $[c]$ acridines, Anticancer Res., 13 (2), 439-442.

[17] Balouiri, M., Sadiki, M., and Ibnsouda, S.K., 2016, Methods for in vitro evaluating antimicrobial activity: A review, J. Pharm. Anal., 6 (2), 71-79.

[18] Braca, A., De Tommasi, N., Di Bari, L., Pizza, C., Politi, M., and Morelli, I., 2001, Antioxidant principles from Bauhinia tarapotensis, J. Nat. Prod., 64 (7), 892-895.

[19] Zhao, C., Sakaguchi, T., Fujita, K., Ito, H., Nishida, N., Nagatomo, A., Tanaka-Azuma, Y., and Katakura, Y., 2016, Pomegranate-derived polyphenols reduce reactive oxygen species production via SIRT3mediated SOD2 activation, Oxid. Med. Cell. Longevity, 2016, 2927131.

[20] Tong, S.Y.C., Davis, J.S., Eichenberger, E., Holland, T.L., and Fowler, V.G.Jr., 2015, Staphylococcus aureus infections: Epidemiology, pathophysiology, clinical manifestations, and management, Clin. Microbiol. Rev., 28 (3), 603-661.

[21] Hennekinne, J.A., De Buyser, M.L., and Dragacci, S., 2012, Staphylococcus aureus and its food poisoning toxins: Characterization and outbreak investigation, FEMS Microbiol. Rev., 36 (4), 815-836.

[22] Croxen, M.A., Law, R.J., Scholz, R., Keeney, K.M., Wlodarska, M., and Finlay, B.B., 2013, Recent advances in understanding enteric pathogenic
Escherichia coli, Clin. Microbiol. Rev., 26 (4), 822880.

[23] Anderson, A.C., Jonas, D., Huber, I., Karygianni, L., Wölber, J., Hellwig, E., Arweiler, N., Vach, K., Wittmer, A., and Al-Ahmad, A., 2016, Enterococcus faecalis from food, clinical specimens, and oral sites: Prevalence of virulence factors in association with biofilm formation, Front. Microbiol., 6, 1534.

[24] Paczosa, M.K., and Mecsas, J., 2016, Klebsiella pneumoniae: Going on the offense with a strong defense, Microbiol. Mol. Biol. Rev., 80 (3), 629-661.

[25] Howard, A., O'Donoghue, M., Feeney, A., and Sleator, R.D., 2012, Acinetobacter baumannii; an emerging opportunistic pathogen, Virulence, 3 (3), 243-250.

[26] Duraisingham, S.S., Hanson, S., Buckland, M., Grigoriadou, S., and Longhurst, H.J., 2014, Pseudomonas infection in antibody deficient patients, Eur. J. Microbiol. Immunol., 4 (4), 198-203.

[27] Martins, N., Barros, L., Henriques, M., Silva, S., and Ferreira, I.C.F.R., 2015, In vivo anti-candida activity of phenolic extracts and compounds: Future perspectives focusing on effective clinical interventions, BioMed Res. I., 2015, 247382.

[28] Ajani, O.O., Joseph, O.E., Iyaye, K.T., October, N., Aderohunmu, D.V., Olorunshola, S.J., and Audu, O.Y., 2020, Facile synthesis, characterization and in vitro antibacterial efficacy of functionalized 2substituted benzimidazole motifs, Indones. J. Chem., 20 (1), 72-87. 